\title{
СТИЛІСТИЧНІ ФУНКЦЇ̈ СКЛАДНИХ БЕЗСПОЛУЧНИКОВИХ РЕЧЕНЬ У ПОЕЗІЇ В. СИМОНЕНКА
}

\footnotetext{
Вавринюк Т. І. Стилстичні функції складних безсполучникових речень у поезії В. Симоненка

У статті досліджено стилістичну роль складних безсполучникових речень у поетичних творах В. Симоненка. Визначено, що безсполучникові конструкції приховують у собі великі експресивні можливості: підсилюють ритмічність тексту, створюють стилістичну синтаксичну 
фігуру - асиндетон, яка (залежно від структурно-семантичного типу речення) може бути засобом поетичної градації, образного паралелізму чи антитези.

Ключові слова: безсполучникові складні речення, експресивність, асиндетон, градація, паралелізм, антитеза.

Вавринюк Т.И. Стилистические функции сложных бессоюзных предложений в поэзии В. Симоненко.

В статье исследована стилистическая роль сложных бессоюзных предложений в поэтических произведениях В. Симоненко. Определенно, что бессоюзные конструкции скрывают в себе большие экспрессивные возможности: усиливают ритмичность текста, создают стилистическую синтаксическую фигуру - асиндетон, которая (в зависимости от структурносемантического типа предложения) может быть средством поэтической градации, образного параллелизма или антитезы.

Ключевые слова: бессоюзные сложные предложения, экспрессивность, асиндетон, градация, параллелизм, антитеза.

Vavrynyuk T. I. Stylistic functions of compound sentences joined asyndentically are in the poems of V. Simonenko.

In the article the stylistic role of compound sentences joined asyndentically in poetic works of V. Simonenko is investigated. Certainly, that asyndetic constructions have large expressive possibilities. They strengthen the rhythm of text, create a stylistic syntactic figure - asindeton, which (depending on the structurally-semantic type of suggestion) can be the mean of poetic gradation, vivid parallelism or antitheses.

Key words: asyndetic difficult suggestions, expressivity, asindeton, gradation, parallelism, antithesis.

У вітчизняній лінгвістиці статус безсполучникових речень на сьогодні залишається проблематичним: лінгвісти або виділяють їх в окремий тип (С. Дорошенко, Б. Кулик, Л. Кадомцева, С. Бевзенко, К. Шульжук та ін.), або виводять за межі речення (I. Слинько, Н. Гуйванюк, М. Кобилянська), або ж розподіляють між складносурядними і складнопідрядними реченнями. Наприклад, I. Вихованець, відносить до складносурядних безсполучникові конструкції з часовими відношеннями між частинами, а до складнопідрядних - безсполучникові речення, у яких друга частина стоїть у позиції другорядного члена і підпорядкована опорним предикатним словам першої частини типу казати, мовити, думати, знати, пам'ятати, бачити [1, с. 304-306; 321-322]. Решту конструкцій учений розглядає як складні безсполучникові речення 3 недиференційованим синтаксичним зв'язком між частинами [1, с. 347-349]. С. Дорошенко, який розглядає безсполучникові складні речення як окремий тип складних структур, підкреслює, що «безсполучникові складні речення - синтаксичні одиниці, які відзначаються специфічним змістом і своєрідним стилістичним забарвленням у порівнянні з іншими видами сполучникових складних речень - складносурядних i складнопідрядних» [2, с. 29].

Отже, особлива стилістична роль складних безсполучникових речень зумовлена їх синтаксичною природою: істотна роль інтонації в розпізнаванні смислу і синтаксичного значення цих речень; а у вираженні синтаксичних відношень між предикативними компонентами мають такі чинники, як порядок розташування частин, видо-часові співвідношення дієслів-присудків, наявність лексичних елементів відповідної семантики тощо. 
Безсполучникові складні речення досить неоднорідні за своєю структурою і характеризуються багатством і різноманітністю семантичних відношень між предикативними частинами. Крім того, у безсполучникових складних реченнях інтонаційний малюнок $\epsilon$ мелодійно барвистим, різнозначним, тому безсполучникові речення більш властиві усному мовленню та поетичному мовленню, де конче потрібна багатогранність значеннєвих відтінків. Стилістичні особливості безсполучникових складних речень полягають у тому, що вони недостатньо чітко виражають характер відношення між частинами і приховують у собі великі експресивні можливості, оскільки в них більшої значимості набуває інтонація як основний засіб зв'язку між частинами.

У досліджених нами поетичних творах В. Симоненка безсполучникові складні речення відзначаються високою частотністю функціонування: ми виявили всі структурно-семантичні типи безсполучникових речень. Окремі тексти («Моралісти нас довго вчили...» (3, с. 29); «Ой майнули білі коні...» (3, с. 133) та ін.) складаються лише із безсполучникових речень, а в поезії «Лебеді материнства» (3, с. 10) із 15 речень лише 2 сполучникові, інші безсполучникові структури. Така синтаксична організація тексту разом із метро-ритмічними засобами створює особливу мелодику вірша:

Ой майнули білі коні,

тільки в'ються гриви,

Тільки курява лягає

на зелені ниви.

Пронеслись, прогуркотіли,

врізалися в небо,

Впала з воза моя мрія -

пішки йде до тебе.

Знаю: дійде, не охляне,

в полі не зачахне -

Світ твоїми, моя люба,

кучерями пахне!

Крізь пилюку, по багнюиі,

в холод $і$ завію

Прийде чистою до тебе

біла моя мрія (3, с. 133).

Поширені в досліджених поезіях безсполучникові складні речення з однорідними частинами. Ці конструкції автор використовує i для опису природи, і для відтворення певних подій, наприклад: Мерехтять у тумані вогні, Впали роси на заспані трави... (3, с. 35); Я йшов $і$ йшов по синім узбережжі, мовчали гордо скелі кам'яні (3, с. 59); Трави в'януть під млосною спекою, Крутитть вітер серпневий пил, Осокори за даллю далекою Підпирають в степу 
небосхил $(3$, с. 61$)$.

Значне стилістичне і смислове навантаження несуть ті структури, у яких повторюються одні й ті самі члени речення, наприклад: Виростеш ти, сину, вирушиш в дорогу, Виростуть з тобою приспані тривоги (3, с. 10); Чую ваш голос простий $i$ ласкавий, Предки безсмертні мої: Праця людини - окраса $і$ слава, праця людини безсмертя їі! (3, с. 16); Біг чоловік через поле дике, Біг чоловік через темний ліс, Повну вулицю лементу й крику У легенях набряклих ніс (3, с. 156). Подібним структурам у поетичних творах притаманна особлива експресивність.

Безсполучниковість дозволяє підкреслити семантично значимий компонент за рахунок винесення його в абсолютну препозицію, особливо якщо цей компонент посилюється анафорою: Найогидніші очі порожні, Найгрізніше мовчить гроза, Найнікчемніші дурні вельможні, Найпідліша брехлива сльоза (3, с. 62).

Безсполучникові речення з часовими відношеннями, що виражають у складових частинах одночасність дій або станів, становлять найчисельнішу групу серед безсполучникових структур збірки В. Симоненка «Лебеді материнства». Ці речення можуть створювати поетичну градацію, якщо їх предикативні частини доповнюють одна одну, розширюють коло зображуваного: $B$ букварях ти наряджена $i$ заспідничена, Поворозками зв'язана, ледве жива, На обличчі тремтить в тебе радість позичена, На губах скам'яніли казенні слова (3, с. 30); Лиже полум'я жовте черево, Важкувато сопе димар, Галасує від болю дерево, Піднімаючись димом до хмар (3, с. 28).

Реченням із зіставно-протиставними відношеннями між частинами властива експресія, образність. Інтонація в цих конструкціях загалом відповідає інтонації розповідного речення: поступове підвищення тону в першій частині, зниження - у другій. Зіставні відношення виявляються в різних безсполучникових порівняльних конструкціях, протиставні - тільки в конструкціях 3 контрастним порівнянням.

У поетичному мовленні безсполучникові зіставні конструкції поширені як художні форми вислову без яскравих значень порівняння, а лише як форми образного паралелізму: Жоден вітер сония не остудить, півень землю всю не розгребе (3, с. 12); Хай сатаніють виродки од крику нас не знобить од їхньої хули: нам жорна ті із кам'яного віку на танках варвари з Свропи принесли (3, с. 24); Встало сонц̧е $i$ впало в очі, Хмари втому зняли з плечей - Служать людям изі руки робочі, Сонце гріє людям з очей (3, с. 56). Такі речення відзначаются особливим емоційноекспресивним забарвленням.

Якщо в компонентах речення симетрично співвідносяться слова протилежного значення або й різні слова одного класифікаційного ряду, 
безсполучниковий зв'язок однорідності має ясний протиставний відтінок, напр.: Можеш вибирати друзів і дружину, Вибрати не можна тільки Батьківщину (3, с. 10); Можна все на світі вибирати, сину, Вибрати не можна тільки Батьківщину (3, с. 10). У всіх цих прикладах достатнім розділовим знаком $\epsilon$ кома між компонентами, але при посиленому протиставленні вживається тире, напр.: Hi, сонний спокій зовсім нам не сниться, Hi, нас не вабить ніжна тиина - Прийдешнє осяває наші лиия, неспокій творчий з вічністю єдна (3, с. 58).

Часто однорідний безсполучниковий зв'язок увиразнюється i скріплюється відносним стосунком особового займенника другого (наступних) компонента з іменником чи особовим займенником першого компонента - вони означають один і той самий предмет; другий та подальші компоненти цих речень продовжують і розвивають сказане в першому компоненті, по-різному пояснюючи й уточнюючи його. Наприклад: Вкраїнонько! Гуде твоє багаття, убогість корчиться $i$ дотлівае в нім (3, с. 34); Заглядає в шибку казка сивими очима, Материнська добра ласка в неї за плечима (3, с. 10).

Експресивністю відзначаються безсполучникові структури, які складаються із предикативних частин бажальної модальності: Хай брехня твоє слово дугою не вигне, Хай не вірить твій розум в убогі дива (3, с. 30); Хай шалені гудуть над планетою весни, хай трава пнеться вгору крізь листя старе... (3, с. 32).

Широку картину подій, що відбуваються одночасно відтворює контекст із поєднання простих і безсполучникових речень: Я дивлюся в твої перелякані очі, Я тебе заголубить, запестити хочу. Тільки знаю: не треба! Не треба! Міг раніше я жить $і$ не думать про тебе (3, с.130); Дотлівас холод мій у ватрі, я один замріяний іду... Ми тоді зустрілися в театрі, На гальориі в третьому ряду (3, с. 126); Ось на тому й ущухла злива, розійшлися з під'їзу всі. Ти брела по струмках щаслива в загадковій свойй красі (3, с. 118).

Подібне чергування простих речень i складних безсполучникових створює своєрідну ритмічність тексту, охоплює ширші картини, поглиблює семантику зображуваного. Просте речення в таких випадках, як правило, змальовує важливий факт, значиму деталь, які стосуються змісту безсполучникової конструкції.

Речення $з$ неоднорідною безсполучниковістю в досліджуваних творах реалізуються у різних структурно-семантичних варіантах. Безсполучникові складні речення, перший компонент яких має пояснюваний член (дієслово або станівник із семантикою мислення, відчуття, сприймання, психічного стану, буття тощо), а другий компонент розкриває конкретну суть такого пояснюваного члена, - відзначаються чітким актуальним членуванням: перший компонент означає тему вислову, а другий рему. Наприклад: Моралісти нас довго вчили, Вибивалися 3 
кволих сил - Мов, людині потрібні крила, Їй ніяк не можна без крил (3, с. 29); Мені здасться, - може, я не знаю, - Було і буде так у всі часи: Любов, як соние світу відкриває Безмежну велич людської краси (3, с. 106).

Складні безсполучникові речення з пояснювальними відношеннями можуть мати уточнювальний відтінок, якщо у них зміст першого компонента, що означає тему, загальніший, а зміст другого або другого й наступних, які разом відповідають на запитання а саме?, виражаючи рему, є уточнювальним, наприклад: Вельможі пихаті і горді Плетуть родоводів в'язь: В одного - прапрадід став лордом, в іншого - прадід князь (3, с. 37); У житті немов на іподромі: на коні побудеш і під ним (3, с. 158).

Речення 3 причиново-наслідковими відтінками характеризуються тим, що перший компонент цих речень, означаючи тему, повідомляє щось особливе, а другий компонент, виражаючи рему, пояснює чи умотивовує його причину - в значенні бо, адже, тому щцо й відповідає на запитання чому? Цих речень у текстах багато, вони різноманітні, наприклад.: Без неї рими точні й милозвучні Не варті навіть драного гроша - Слова звучать примусить сильно й гучно Лише одна поетова душа (3, с. 68); Гетьте із мулу якорі іржаві - Нидіє на якорі душа!.. (3, с. 12).

Перший компонент речень наслідкового відтінку означає тему, повідомляючи дію, що спричиняє наслідок або логічний висновок, викладений другим компонентом, який виражає рему, напр.: Сnaди мені дощем на груди, Пустелю-душу ороси - Я стану жить (3, с. 115); Полоснули ятагани - Блискавки - донизу (3, с. 107).

Поширеними в досліджених текстах $\epsilon$ складні безсполучникові речення 3 приєднувальним модально-оцінним відтінком. У першому компоненті цих речень повідомляється факт, що став темою для того авторського доповнення, яке являє собою рему: Він в мареннях не раз вершини слави Сягав і досягнуть ніяк не міг - Замість вінків лаврових для забави Йому череп'я кидали до ніг (1, с. 34); Звиняйте за грубе слово - Я з вами свиней не пас! (3, с. 38); Гранітні обеліски, як медузи, Повзли $i$ вибилися з сил - На ивинтарі розстріляних ілюзій Уже не має місия для могил $(3$, с. 38$)$.

Отже, у досліджених художніх текстах активно функціонують складні безсполучникові речення як елементарні, так і багатокомпонентні. Семантика складових предикативних частин зумовлює різноманітність відношень між ними та їх стилістичне навантаження. На основі відсутності сполучникового зв'язку між частинами складного речення створюється стилістична синтаксична фігура - асиндетон, яка (залежно від структурно-семантичного типу речення) може бути засобом поетичної градації, образного паралелізму чи антитези. Речення 3 причиново-наслідковими відтінками характеризуються чіткою актуальною членованістю (перший компонент цих речень означає тему, а другий компонент - рему), що однозначно точно передає авторські акценти. 
Стилістично виразні, семантично місткі, легкі й яскраві, структурно різноманітні асиндетонічні структури задовольняють складні й різноманітні семантико-стилістичні вимоги.

\section{Література}

1. Вихованець I. Р. Граматика української мови. Синтаксис : Підручник / Іван Романович Вихованець. - К. : Либідь. - 1993. - 368 с.

2. Дорошенко С. І. Складні безсполучникові конструкції в сучасній українській мові : [монографія] / Сергій Іванович Дорошенко. - Х. : Вид-во Харків. ун-ту, 1980. - 192 с.

3. Симоненко В. Лебеді материнства : Поезія, проза / Василь Симоненко. - Дн-ськ: Промінь, 1989. $-224 \mathrm{c}$

4. Слинько I. І. Синтаксис сучасної української мови : Проблемні питання : [навч. посібник] / Слинько І. І., Гуйванюк Н. Г., Кобилянська М. Ф. - К. : Вища школа, 1994. - 670 с. 